\title{
Vegetable Oils of Soybean, Sunflower and Tung as Alternative Fuels for Compression Ignition Engines*
}

\author{
R. M. Hartmann**, N. N. Garzón, E. M. Hartmann, A. A. M. Oliveira, E. Bazzo \\ Laboratory for Combustion and Thermal Systems Engineering, Mechanical Engineering Department, \\ Federal University of Santa Catarina, 88040-900, Florianópolis, SC, Brazil \\ E-mail: ricardo@labcet.ufsc.br
}

\begin{abstract}
This work assess the technical viability of the use of straight vegetable oils as fuel for a compression ignition engine applied to distributed electric generation. The use of neat soybean, sunflower, and tung oils, three vegetable oils with potential for application in southern Brazil, was assessed. For this purpose, an electronically controlled conversion kit that preheats the fuel to a proper temperature was developed and adapted to a single-cylinder, naturally aspired, mechanically injected and controlled, compression ignition engine. The engine performance in a steady-state dynamometric cell, in terms of power, torque, specific fuel consumption, and emissions, using vegetable oils, was measured and compared to the performance for neat diesel oil. The neat diesel oil resulted in the highest brake power and the neat tung oil resulted in the lowest, with the relative difference among all fuels varying between $5 \%$ and $20 \%$. However, the first law efficiency was highest for some of the blends tested, reaching $38 \%$, and increased for lower speed. The $\mathrm{NO}_{\mathrm{x}}$ and $\mathrm{CO}$ emissions both increased as the engine speed decreased, revealing the lack of complete combustion especially in the higher speed regime.
\end{abstract}

Keywords: Renewable energy, vegetable oils, biofuels, compression ignition engine.

\section{Introduction}

The use of complementary sources for the Brazilian energetic matrix has been sought by government and corporative stakeholders. Biofuels are the choice for transportation, either as a neat fuel or as an additive to petroleum derived fuels (Martines-Filho et al., 2006; Pousa et al., 2007). Brazilian legislation allows the use of ethanol in spark ignition engines mixed with gasoline in volumetric fractions from $20 \%$ to $100 \%$, while biodiesel has also been mixed to diesel oil in a 5\% volumetric basis. This has led to the increase in the fuel octane rating for spark ignition (SI) engines, the reduction of the sulfur content in fuels for compression ignition (CI) engines, and to the prospect of a more sustainable transportation energy matrix. Sugar cane is the main source for ethanol, which is cultivated in areas where it does not compete to food production. Byproducts of the ethanol industry, such as the sugar cane bagasse, are converted to electrical energy. Well to wheel life cycle analysis point to zero (or negative) GhG contribution (Luo, van der Voet \& Huppes, 2009; Macedo et al., 2004; Ometto et al., 2009). There are also niche applications in which the presence of biofuels could increase. For example, isolated communities in the Brazilian northern states use diesel oil for electrical energy generation. This diesel consumption could be displaced by a more environmentally friendly and economical fuel mix (Andrade \& Miccolis, 2010). Rural areas can also benefit from the use of locally produced fuels. In this scenario, oil from vegetable and animal sources could provide alternative solutions for transportation and energy generation for isolated areas.
One of the routes for the use of vegetable oil and fats is the transesterification that leads to monoalkyl esters known as biodiesel (Shahid \& Jamal, 2011). Several studies have shown that biodiesel can displace diesel oil without the need for any modifications in CI engines, both for transportation or stationary applications (Agarwal , 2007; Dwivedi et al., 2006). However, this requires an industrial transesterification process that carries its own intrinsic complexities and costs. A more direct approach would be the use of straight vegetable oil in CI engines, obtained after filtration only, with a minimum of modification of the engine's hardware (Sidibé et al., 2010). Historically, there is evidence that Rudolph Diesel conducted tests with peanut oil after 1900 and was supportive of using straight vegetable oils as fuel for CI engines (Knothe, 2001; Knothe et al., 2005). Later on, Chang \& Wan (1947) reported studies carried out in China during the Second World War using neat tung oil as fuel for compression ignition engines. In their work, they presented the performance of a compression ignition engine fuelled with diesel, cotton seed, rapeseed and tung oils. Recent reviews on the use of straight vegetable oils (SVO) may be found in Bhattacharya \& Reddy (1994), Sinha \& Misra (1997), Babu \& Devaradjane (2003), Mondal et al. (2008), and No (2011).

Recent estimates (CONAB, 2011) point that there are in Brazil more than 20 varieties of crops that produce vegeta-ble oils. Among them, the varieties that have national or regional interest are soybean, castor beans, sunflower, peanut, cottonseed, babassu, palm, jatropha, and canola. 
Table 1. List of the literature reporting tests in CI engines fuelled with raw vegetable oils and their mixtures with diesel oil.

\begin{tabular}{|c|c|}
\hline Common name (Botanical name) & References \\
\hline \multicolumn{2}{|l|}{ Edible Oils } \\
\hline Soybean (Glycine max) & Altin et al. (2001); Engelman et al. (1978); Pryor et al. (1983). \\
\hline Rapeseed (Brassica napus) & $\begin{array}{l}\text { Bialkowski et al. (2005); Hazar \& Aydin (2010); Kleinova et al. } \\
\text { (2009); Nwafor (2003); Peterson et al. (1983); Yilmaz \& Morton } \\
\text { (2011). }\end{array}$ \\
\hline Palm (Elaeis guineensis) & $\begin{array}{l}\text { Almeida et al. (2002); Antwi (2008); Bari \& Roy (1995); Belchior \& } \\
\text { Pimentel (2005); Sapaun et al. (1996). }\end{array}$ \\
\hline Coconut (Cocos nucifera) & Antwi (2008); Kalam et al. (2003); Thaddeus et al. (2001). \\
\hline Cottonseed (Gossypium hirsutum and Gossypium herbaceum) & $\begin{array}{l}\text { Altin et al. (2001); Amba \& Rama (2003); He \& Bao (2005); Fontaras } \\
\text { et al. (2007); Sarada et al. (2010); Balafoutis et al. (2011); Martin \& } \\
\text { Prithviraj (2011). }\end{array}$ \\
\hline Corn $($ Zea mays $)$ & Altin et al. (2001). \\
\hline Olive (Olea europaea) & Rakopoulos et al. (2011). \\
\hline Sunflower (Helianthus annuus) & $\begin{array}{l}\text { Altin et al. (2001); Karaosmanoglu et al. (2000); Maziero et al. (2007); } \\
\text { Yilmaz \& Morton (2011). }\end{array}$ \\
\hline Peanut (Arachis hypogaea) & Barsic \& Humke (1981); Yilmaz \& Morton (2011). \\
\hline Safflower (Carthamus tinctorius) & Bettis et al. (1982); Isigigur et al. (1993). \\
\hline Sesame (Sesamum indicum) & Altun \& Oner (2009). \\
\hline Rice bran (Oryza sativa) & Agarwal (2007); Bari \& Roy (1995); Raghu et al. (2011). \\
\hline Linseed (or flaxseed) (Linum usitatissimum) & Agarwal (2007). \\
\hline Poppy seed (Papaver somniferum) & Aksoy (2010). \\
\hline Mahua (Madhuca longifolia) & $\begin{array}{l}\text { Agarwal \& Agarwal (2007); Pugazhvadivu \& Sankaranarayanan } \\
\text { (2010). }\end{array}$ \\
\hline Neem (Azadirachta indica or Antelaea azadirachta) & Sivalakshmi \& Balusamy (2011). \\
\hline \multicolumn{2}{|l|}{ Nonedible Oils } \\
\hline Castor seed (Ricinus communis) & Naga et al. (2009). \\
\hline Jatropha (Jatropha curcas) & $\begin{array}{l}\text { Agarwal \& Agarwal (2007); Antwi (2008); Chalatlon et al. (2011); } \\
\text { Chauhan et al. (2010); Forson et al. (2004); Kumar et al. (2003); } \\
\text { Pramanik (2003); Yaodong et al. (2010). }\end{array}$ \\
\hline Pongam (or indian beech, karanja, honge) (Pongamia pinnata) & Agarwal \& Rajamanoharan (2009); Venkanna et al. (2009). \\
\hline Tobacco seed (Nicotiana tabacum) & Giannelos et al. (2002). \\
\hline Tung (Aleurites fordii) & Chang \& Wan (1947). \\
\hline
\end{tabular}

Most of these (and others) have already been tested as neat fuels for CI engines. Table 1 lists oil producing crops that have been tested as straight vegetable oil (SVO) fuel in CI engines in recent years. The references for their use as biodiesel far outnumber those shown and are omitted. Vegetable oils present, comparatively to diesel oil, lower LHV (from $10 \%$ to $17 \%$ lower, leading to lower energy release per mass burned), higher viscosity (leading to poor atomization), higher boiling temperatures (delaying evaporation and formation of a combustible mixture), higher bulk modulus (causing injector to open earlier), higher flash point (delaying mixture ignition), higher oxidation instability (leading to higher tendency to degradation during storage), and a tendency for thickening with time (Babu \& Devaradjane, 2003; Franco \& Nguyen, 2011). When using the same injectors and settings adjusted for diesel fuel, the higher viscosity, surface tension and density of the vegetable oils result in changes in injected oil volumes, injection delay after injector opening, spray patterns (cone and penetration) and atomization (droplet size distribution) (Bialkowski et al., 2005). As a result of poor atomization, mixing and ignition there are:

(a) Longer ignition delay, smaller pressure rise, lower cylinder peak pressure and a longer combustion duration (Venkanna et al., 2009), resulting in 5\% to $25 \%$ (Chalatlon et al., 2011) reduction in thermal efficiency at maximum power when compared to pure diesel oil. (b) The formation of carbon deposits on fuel injectors, ring landings, exhaust valves, and contamination of the lubricating oil by vegetable oil. These effects can severely limit the engine lifespan.

(c) A reduction in the formation of $\mathrm{NO}_{\mathrm{x}}$, but a possible increase in smoke, $\mathrm{CO}$ and $\mathrm{HC}$ (Belchior \& Pimentel, 2005; Pimentel et al., 2004).

Tests with long term operation (> 60 hours) with neat sunflower oil (Maziero et al., 2007) have reported obstruction of the lubricating oil flow galleries, damage of piston rings and gaskets, presence of tar in the exhaust manifolds and the presence of elevated concentration of copper, chromium, iron and lead in the lubricating oil. Bialkowski et al. (2005) reported coking, spray obstruction by lacquer formation at spray tip and engine deterioration. They also reported problems with slow flow along oil lines, filter clogging, and engine oil deterioration.

Since the pioneering work, a few solutions have been proposed and implemented:

(a) The viscosity of the vegetable oil can be reduced by heating (Aksoi, 2010; Forson et al., 2004; Kleinova et al., 2009; Venkanna et al., 2009). The oil temperature before injection has been regulated from $20^{\circ} \mathrm{C}$ (Bialkowski et al., 2005) to $160^{\circ} \mathrm{C}$ (Raghu et al., 2011). Most authors preheat the SVO such as to bring the physical properties closer to those of diesel oil. Most commonly, the oil temperature does not exceed $130^{\circ} \mathrm{C}$ (Pugazhvadivu \& Sankaranarayanan, 2010). 
(b) Blending vegetable oil with diesel also decreases viscosity and improves volatility. These improved properties result in better mixture formation and spray penetration. A number of investigators tried the vegetable oils in varying proportions with diesel. Most remarkably, few studies (Forson et al., 2004) show engine performance even above that of operation with neat diesel oil.

(c) Advanced injection timing compensates the effects of the longer delay period and slower burning rate that is exhibited by vegetable oils (Nwafor \& Rice, 1996). Staged injection may not lead to improvement in fuel/air mixing when it occurs too late along the expansion cycle (Bialkowski et al., 2005).

Most of the recent work was developed using low power single cylinder CI engines fuelled by mechanical pumps (Aksoi, 2010; Altin et al., 2001; Forson et al., 2004; Martin \& Prithviraj, 2011; Pugazhvadivu \& Sankaranarayanan, 2010; Raghu et al., 2011; Sarada et al., 2010; Sivalakshmi \& Balusamy, 2011; Venkanna et al., 2009) in the context of the application of small engines for rural and remote areas. Fewer works were developed with larger engines for general use (Bialkowski et al., 2005), for use in agriculture (Maziero et al., 2007), and for transportation (Chalatlon et al., 2011; Kleinova et al., 2009). Usually, large indirect injection compression ignition engine (IDI) operate better during long duration tests while small IDI and direct injection compression ignition engine (DI) present problems (Bialkowski et al., 2005; He \& Bao, 2005). Only Kleinova et al. (2009) and Bialkowski et al. (2005) have developed their studies using common rail injection systems. Most modern CI engines nowadays employ common rail injection. The use of a central electronic unit and the common rail has enabled great advances in performance and in-cylinder emissions control using diesel oil and these improvements could also be expected when using straight vegetable oils. For example, Venkanna et al. (2009) investigated the effect of the injection pressure in a mechanical system, varying the injection pressure from 200 bar to 280 bar. Even in this small range they measured differences in thermal efficiency that point out to an optimum operation pressure for a given combustion chamber, injector and oil temperature. They argue that, for their engine, a further increase in pressure would cause an excessive diminution of droplet sizes and insufficient spray penetration. They also noticed that smoke reduces continually with the increase in pressure. This indicates the need to explore further the effects of injection pressure, injection timing, and split injection.

Here, tests of a mechanical injected engine in a dynamometric bench operating with straight vegetable oils of Soybean, Sunflower and Tung and their mixtures with diesel oil are reported. This work relies on the assumption that oil heating and higher injection pressure contribute to a better spray development and atomization, leading to better performance, efficiency and smaller emission of smoke. The basic strategy for pre-heating consists in bringing the straight vegetable oil before the injector to a temperature in which the viscosity of the oil approaches that of the diesel oil at ambient temperature. To allow for the control of the fuel heating an electronically controlled heating unit was developed and adapted to the engine. This set up is described next.

\section{Experiment}

\subsection{Engine and instrumentation}

The study was carried out in a single cylinder, four strokes, direct injection, mechanically pumped and controlled, CI engine. Table 2 lists the main characteristics of the engine. This is a sturdy, small engine, typically used for electrical energy generation in isolated communities. The engine was coupled to a Schenck W70, eddie current dynamometer. The torque was measured with an Hbm Wagezelle extensometer type load cell and the speed was measured with an incremental encoder with resolution of 60 steps. The temperature of the exhaust gases was measured in the exhaust manifold, close to the exhaust valve. The concentration of the exhaust gases were measured with a Testo Portable Gas Analyzer, model 350-XL. The mass of fuel consumed was measured gravimetrically with a Shimadzu electronic balance model UX 8200S. The entire experiment was controlled using the LabVIEW software.

Table 2. Engine basic characteristics.

\begin{tabular}{cc}
\hline Manufacturer & Yanmar \\
Model & YT22 \\
Bore $[\mathrm{mm}]$ & 115 \\
Stroke [mm] & 115 \\
Compression Ratio & 17.3 \\
Displacement volume [cm $\left.{ }^{3}\right]$ & 1194 \\
Nominal conditions: & \\
Speed [rpm] & 2000 \\
Power [kW] & 14.7 \\
BSFC $\left[\mathrm{g}(\mathrm{kWh})^{-1}\right]$ & 238 \\
Injection pressure [bar] & 200 \\
Injection time [ ${ }^{\circ}$ BTDC] & 18 \\
\hline
\end{tabular}

The mechanical speed control system uses a flyball governor for fuel control and as speed limiter, as shown in Figure 1. The engine was adjusted to full load by setting the load handle to its maximum (top) position. The load handle is connected to a spindle that directly acts in the injection pump, controlling the fuel flow. A tensioned spring keeps the spindle arms in contact against the sliding balls. When the engine speed increases, the sliding balls move outwards, releasing the spindle arms. The tensioned spring pulls the spindle in the direction of closing the fuel flow.

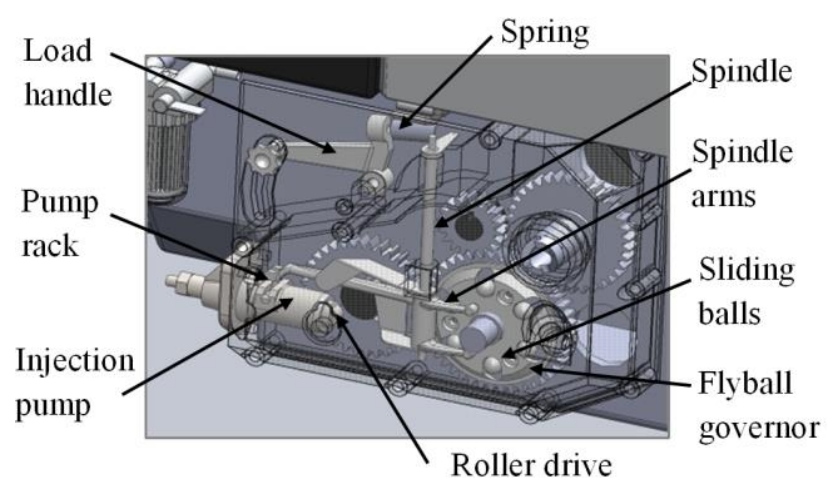

Figure 1. Drawing of the governor subsystem and synchronizing gears. 
As the speed reduces, the sliding balls move back towards the center of the flyball governor, pressing the spindle arms up against the spring and opening the fuel flow. The sensitivity of the control is provided by the design of the curvature of the lever arms, their position in respect to the sliding balls, and the tension of the spring.

\subsection{Fuels analysis}

Three vegetable oils and their blends with commercial Brazilian diesel oil were used. Brazilian diesel oil has a volumetric addition of $5 \%$ of biodiesel, as required by law and regulated by ANP, the National Petroleum Agency. The fuels used are labeled following Table 3.

Table 3. Nomenclature for the fuel mixtures used.

\begin{tabular}{cc}
\hline Nomenclature & Fuel \\
\hline $100 \%$ SW & Straight Sunflower Oil \\
$100 \%$ SY & Straight Soybean Oil \\
$100 \%$ TG & Straight Tung Oil \\
$50 \%$ SW-50\%D & $50 / 50$ v/v Sunflower Oil and diesel oil \\
$50 \%$ SY-50\%D & $50 / 50 \mathrm{v} / \mathrm{v}$ Soybean Oil and diesel oil \\
$50 \%$ TG-50\%D & $50 / 50$ v/v Tung Oil and diesel oil \\
$100 \%$ D & Brazilian commercial diesel oil \\
\hline
\end{tabular}

The straight vegetable oils and their respective mixtures were preheated before injection in the engine. The strategy was to bring the fuel kinematic viscosity to a value close to that of diesel oil at ambient temperature. For that, the viscosities of the fuel mixtures were measured as a function of temperature by standardized viscosity experiments carried out in the Brazilian National Institute of Technology (INT), Rio de Janeiro, RJ. Table 4 summarizes the injection temperature, the kinematic viscosity and the density of the fuel blends. The density was measured gravimetrically using a Kern electronic balance model EW $220-3 \mathrm{NW}$. The fuel temperature was kept sufficiently low to avoid thermal degradation.

Table 4. Injection temperatures and kinematic viscosities.

\begin{tabular}{cccc}
\hline Fuel & $\begin{array}{c}\text { Injection } \\
\text { Temperature } \\
{\left[{ }^{\circ} \mathrm{C}\right]}\end{array}$ & $\begin{array}{c}\text { Kinematic } \\
\text { Viscosity } \\
{\left[\mathrm{mm}^{2} / \mathrm{s}\right]}\end{array}$ & $\begin{array}{c}\text { Density } \\
{\left[\mathrm{kg} / \mathrm{m}^{3}\right]}\end{array}$ \\
\hline $100 \% \mathrm{SW}$ & 85 & 10.52 & 863 \\
$100 \% \mathrm{SY}$ & 85 & 8.48 & 860 \\
$100 \% \mathrm{TG}$ & 95 & 16.33 & 869 \\
$50 \%$ SW-50\%D & 65 & 5.45 & 857 \\
$50 \%$ SY-50\%D & 65 & 5.53 & 856 \\
$50 \%$ TG-50\%D & 85 & 8.26 & 855 \\
$100 \% \mathrm{D}$ & 25 & 4.52 & 846 \\
\hline
\end{tabular}

Table 5 summarizes the energy content of the fuels and fuel blends. The blending rule is a simple mass average of the LHV of the neat fuels. It is observed that the diesel oil has a lower heating value (LHV) about 15\% higher than that of the straight vegetable oils. Table 6 presents the elementary analysis of the vegetable oils. Diesel is modeled as an alkane with formula $\mathrm{C}_{16} \mathrm{H}_{34}$.

Besides preheating the fuels, the temperature must be controlled within a narrow range to avoid any fuel degradation. With that purpose, an electronic control unit (ECU) was developed. The main component of the ECU was a microcontroller model dsPIC. The conversion kit preheated the vegetable oil using the rejected heat of the engine. This heat was recovered from the exhaust gases by a heat exchanger that used a solution of water and mono-ethylene glycol as thermal fluid.
Table 5. Energy content of the fuels and fuel blends.

\begin{tabular}{ccc}
\hline Fuel & $\begin{array}{c}\text { LHV } \\
(\mathrm{kJ} / \mathrm{kg})\end{array}$ & $\begin{array}{c}\text { Ratio in respect } \\
\text { to diesel oil }\end{array}$ \\
\hline $100 \% \mathrm{SW}$ & $36150 \pm 30^{(1)}$ & 0.86 \\
$100 \% \mathrm{SY}$ & $36270 \pm 20^{(1)}$ & 0.86 \\
$100 \% \mathrm{TG}$ & $35750 \pm 30^{(1)}$ & 0.85 \\
$50 \% \mathrm{SW}-50 \% \mathrm{D}$ & $38932^{(2)}$ & 0.93 \\
$50 \% \mathrm{SY}-50 \% \mathrm{D}$ & $38975^{(2)}$ & 0.93 \\
$50 \% \mathrm{TG}-50 \% \mathrm{D}$ & $38946^{(2)}$ & 0.93 \\
$100 \% \mathrm{D}$ & $42000^{(3)}$ & 1.00 \\
\hline \multicolumn{2}{l}{}
\end{tabular}

Table 6. Elementary analysis of the straight vegetable oils.

\begin{tabular}{lcccc}
\hline & Soybean & Sunflower & Tung & Diesel \\
\hline $\mathrm{C}(\mathrm{wt} \%)^{(1)}$ & 76.9 & 77.6 & 77.5 & $84.6^{(4)}$ \\
$\mathrm{H}(\mathrm{wt} \%)^{(1)}$ & 11.4 & 11.3 & 11.4 & $15.4^{(4)}$ \\
$\mathrm{N}(\mathrm{wt} \%)^{(1)}$ & 2.0 & 0.0 & 0.0 & -- \\
$\mathrm{O}(\mathrm{wt} \%)^{(3)}$ & 9.7 & 11,1 & 11.1 & -- \\
$\mathrm{S}(\mathrm{mg} / \mathrm{kg})^{(2)}$ & 1.2 & 1.5 & 0.6 & 1800 \\
\hline
\end{tabular}

(1) ASTM D 5291, (2) ASTM D 5453, (3) Balance, (4) As $\mathrm{C}_{16} \mathrm{H}_{34}$.

The solution was pumped to a second heat exchanger, where the vegetable oils were heated to the selected temperature. The temperature of the vegetable oil was measured at the outlet of the heat exchanger. This value was sent to the ECU that controlled the temperature of the vegetable oils by controlling the flow of the thermal fluid. A second conversion kit that will allow the use of a common rail system is under development. The results reported here were obtained with the mechanical governor.

\subsection{Test procedure}

A typical test began with the engine warm up at full load using neat diesel oil until the temperature of its coolant reached $70^{\circ} \mathrm{C}$. Then, the fuel was switched to the fuel of interest and the engine operation at zero load was allowed to stabilize for $10 \mathrm{~min}$. After stabilizing at zero load, the brake was applied, the engine speed reduced and the engine was allowed to reach steady-state operation at a new speed. The procedure was repeated until the engine speed reached $1500 \mathrm{rpm}$. About 10 operation points were recorded for each fuel and fuel blend.

Each complete run took about 2 hours. After each steady-state, the engine speed, torque, coolant temperature, fuel mass, fuel temperature, inlet air humidity and temperature, exhaust gas temperature and concentration of $\mathrm{CO}, \mathrm{CO}_{2}$, and $\mathrm{NO}_{\mathrm{x}}$ were recorded. Each complete run was repeated at least three times, until statistical repeatability was observed.

\subsection{Measurement uncertainties}

The uncertainty of the reported measurements was estimated based on the uncertainty of each instrument used for the measurement of the base variables and with the statistical uncertainty related to the number of experiments. Table 7 summarizes the expanded uncertainties. It can be observed that the measurement of emissions has the greater expanded uncertainty while the results obtained in the dynamometric bench are associated to smaller uncertainties. 
Table 7. Expanded uncertainty ${ }^{(1)}$ of each measurement.

Measurement $\quad$ Expanded Uncertainty [\%]

Engine speed \pm 2.5

Torque

$\pm 2.8$

Power

$\pm 2$

Fuel mass flow rate

$\pm 5$

$\pm 4$

$\pm 4$

$\pm 9$

$\pm 5$

$\mathrm{NO}_{\mathrm{x}}$ mole fraction $\quad \pm 8$

Exhaust gas temperature

(1) Expanded uncertainty as a percentage of the mean value for a probability of $95 \%$.

\section{Results and discussion}

In this section, the results obtained in the dynamometric bench are shown. Figures 2 and 3 present power, figures 4 and 5 present fuel consumption, figure 6 presents the thermal efficiency, and figures 7 to 9 present emissions and exhaust gas temperature.

Figure 2 presents the engine power as a function of engine speed for the three SVO and their blends with diesel oil. The measurements are represented by the symbols. The interpolating continuous lines are used only as a guide to the eyes. The measurements for speeds above $2000 \mathrm{rpm}$ are affected by the governor and the curves for all fuels fall to similar values. Therefore, in the figures that follow all measurements taken above 2000 rpm are not presented. Figure 3 presents the percentage variation in engine power when compared to neat diesel oil.

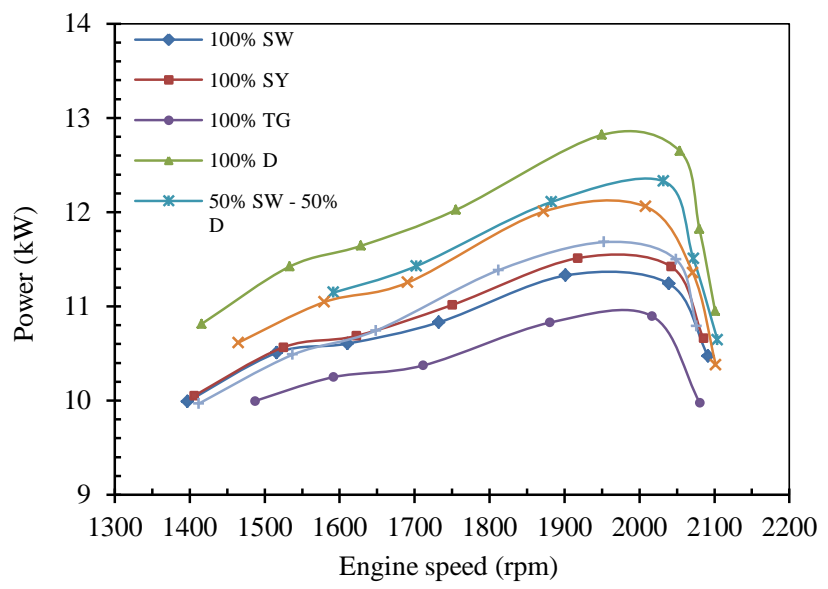

Figure 2. Engine power versus engine speed.

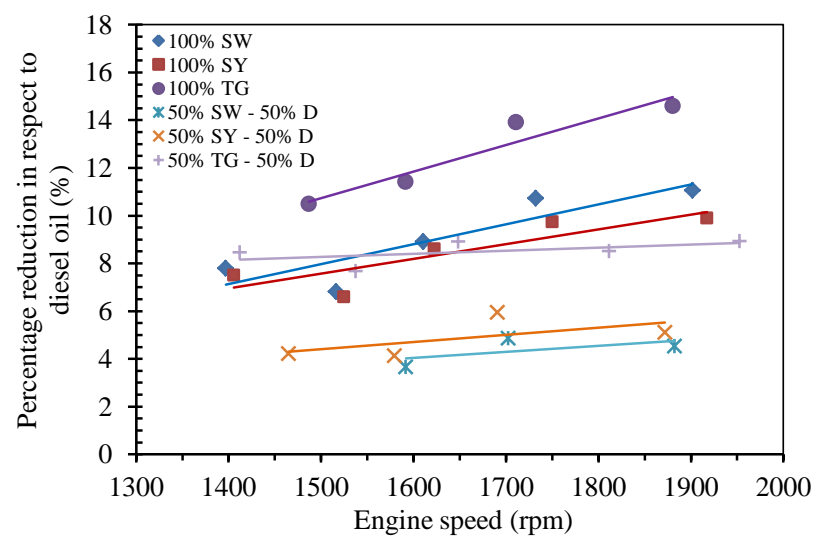

Figure 3. Percentage reduction in power when compared to the operation with diesel fuel.
In order to better understand the results of performance in Figures 2 and 3, initially, the mass of fuel injected is discussed.

\subsection{Engine control and fuel consumption}

Figure 4 presents the mean fuel mass injected per cycle as a function of engine speed. Within the measurement uncertainty, all fuels presented the same values, indicating the good match of the kinematic viscosities. This fixes a basis for comparison, i.e., all measurements at a given engine speed occurred with approximately the same mass of fuel injected per cycle. In Figure 4 , it is also noticed that the fuel mass increased approximately linearly with the decrease of the engine speed. The mechanical control of the fuel injection acted in the direction of keeping a constant engine speed. Therefore, as the load in the engine was increased and the speed reduced, the mass of fuel injected per cycle was increased. This increase was approximately linear due to the design of the governor. However, we note that the fuel mass flow rate increases with engine speed, as shown in Figure 5.

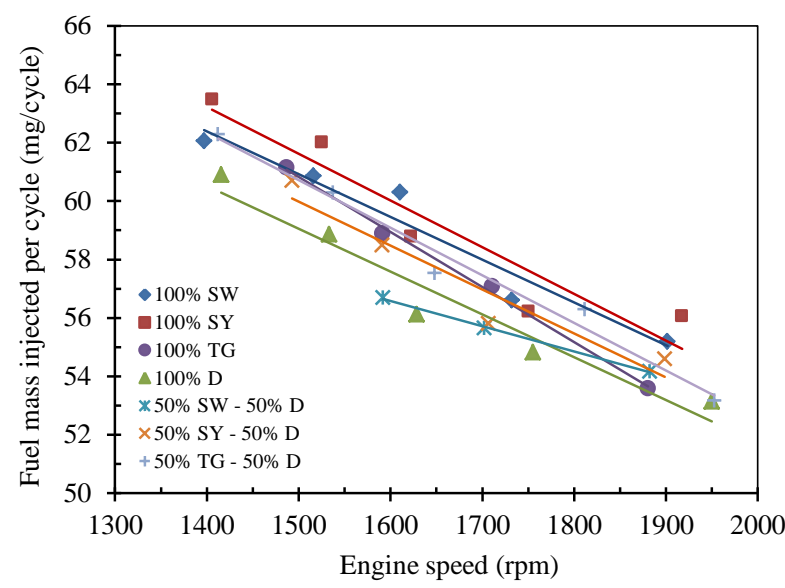

Figure 4. Fuel mass injected per cycle versus engine speed.

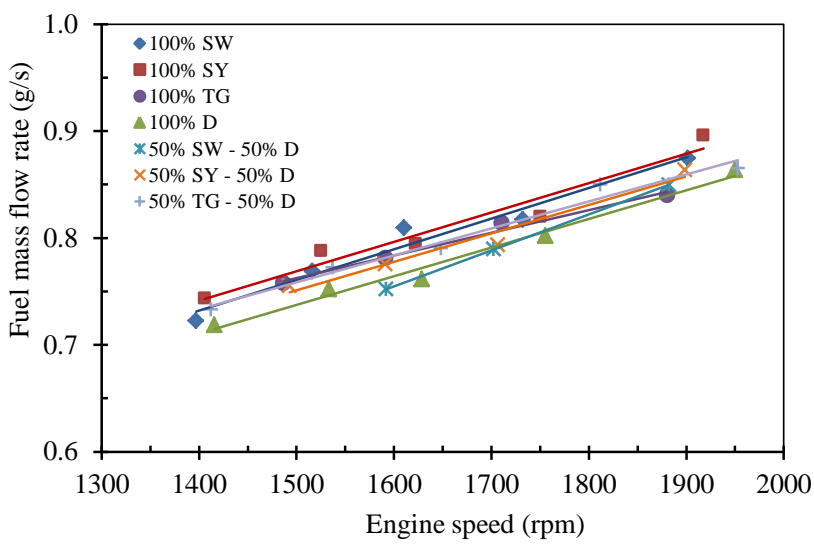

Figure 5. Fuel mass flow rate versus engine speed.

\subsection{Engine performance}

The results in Figure 2 can be separated in four groups, from the higher to the lower performance, formed by, respectively: (1) The diesel oil, (2) the blends of soybean and sunflower oils, (3) the straight soybean, sunflower and the blend of tung oil, and (4) the straight tung oil. This is in accordance with the distribution of 
viscosities presented in Table 4 . For the neat fuels, the power increases in the sequence tung, soybean, sunflower, and diesel oil, in all speeds. This behavior is also commonly reported in the literature (Aksoi, 2010; Altin et al., 2001; Chalatlon et al., 2011; Kleinova et al., 2009; Martin \& Prithviraj, 2011; Maziero et al., 2007; Pugazhvadivu \& Sankaranarayanan, 2010; Raghu et al., 2011; Sarada et al., 2010; Sivalakshmi \& Balusamy, 2011; Venkanna et al., 2009). As an exception, Balafoutis et al. (2011) reported higher power at higher loads when using cottonseed, rapeseed and sunflower in a turbo charged, CI engine. In their tests, at high loads, the speed reduced and the specific consumption increased. They explained the higher power output as a result of the larger time available to evaporate and burn a higher amount of fuel when the load was increased. Here, since the mass injected per cycle was the same for all fuels, the engine power was always higher for the diesel oil.

Figure 3 presents the percentage variation in engine power when compared to neat diesel oil. We notice that tung oil resulted in the lower power, about $15 \%$ smaller than the power produced by the diesel oil at the speed of $1900 \mathrm{rpm}$. This is the same relation that exists between the LHV of both fuels, according to Table 5. However, although the other fuels also present an approximate $15 \%$ reduction in LHV, the reduction in maximum power is smaller. Since the mass of fuel injected per cycle was the same for all fuels (Figure 4), this indicates that the fuel conversion efficiency improved for both soybean and sunflower.

The blending with diesel oil increased the power output for all SVO, but it still remained smaller than that for neat diesel oil. Both blends of sunflower and soybean equally approximate the power delivered by neat diesel oil, with only a 5\% decrease at $1900 \mathrm{rpm}$. This is possibly an effect of the decrease in ignition delay caused by the presence of the diesel oil, aiding at atomization, evaporation and ignition of the SVO fraction. From Table 4 , we also observe that the viscosity increase in the sequence diesel oil, soybean oil, sunflower oil and tung oil. The peak power presented in Figure 2 decreases accordingly in the same sequence.

Figure 6 presents the brake specific fuel consumption as a function of engine speed for the different oils and their blends. The uncertainty in the values of BSFC is estimated in 5\%. Although the fuel mass injected per cycle decreases, the BSFC increases with speed. Balafoutis et al. (2011) report $229 \mathrm{~g} / \mathrm{kWh}$ as the best BSFC for their engine operating with neat diesel oil. Also, they report a $15 \%$ maximum increase in BSFC for operation with neat sunflower oil. For this engine, the best BSFC with diesel oil is $235 \mathrm{~g} / \mathrm{kWh}$.

Also, a maximum increase of $17 \%$ was measured for the operation with sunflower. Since this is a naturally aspirated engine with a mechanical pump, the values measured are reasonable. All vegetable oils and blends resulted in higher BSFC when compared to diesel oil. Neat tung oil resulted in a maximum increase of BSFC of $21 \%$ in respect to neat diesel operation. Also, the BSFC does not scale linearly with the blending. For example, the blend with $50 \%$ soybean oil resulted in only a $5 \%$ increase of BSFC over that of diesel oil, while $100 \%$ soybean presented an increase of $15 \%$.

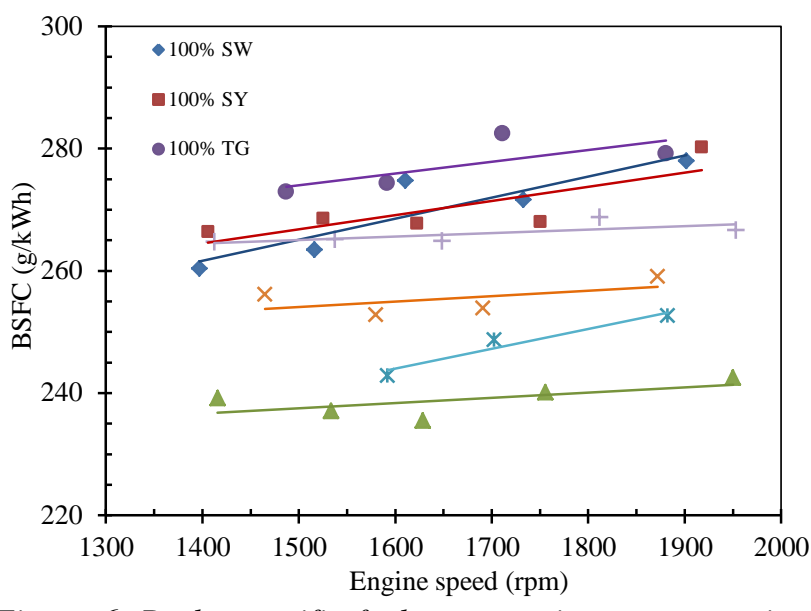

Figure 6. Brake specific fuel consumption versus engine speed.

\subsection{First law thermal efficiency}

Figure 7 presents the first law efficiency, or fuel conversion efficiency, as a function of engine speed. Although the thermal efficiency for the blend of tung oil is smaller than that for diesel oil, the efficiency for all the other fuels is in fact higher. The variation of the efficiency with the speed is within the measurement uncertainty for the neat diesel oil and for the blend of soybean oil. All other efficiencies decrease with the increase of engine speed. Balafoutis et al. (2011) have reported an increase of $8 \%$ over the efficiency of neat diesel oil when neat rapeseed oil is used (reaching $39 \%$ thermal efficiency), $2 \%$ with cotton seed and a drop of 3 $\%$ for sunflower. Here, best efficiencies (around $38 \%$ ) are achieved with sunflower, which is about $6 \%$ higher than that for neat diesel. Remarkably, Forson et al. (2004) reported a $33 \%$ increase in thermal efficiency over neat diesel for a $2.6 \%$ jatropha oil blend (reaching $20 \%$ thermal efficiency). Somehow, there is some improvement in fuel conversion when the fuels are mixed.

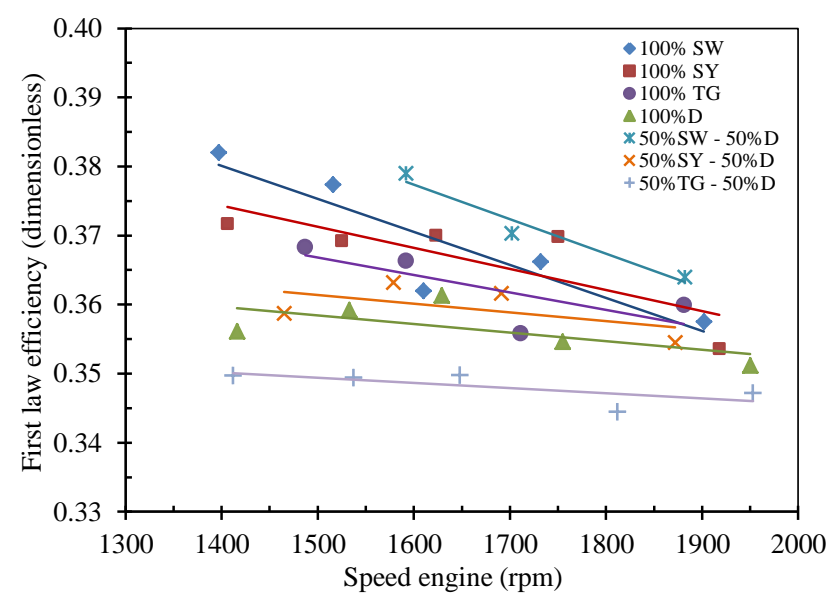

Figure 7. First law (fuel conversion) efficiency versus engine speed.

\subsection{Emission of gas pollutants}

Figure 7 presents the mole fraction of $\mathrm{CO}$ in the exhaust gases as a function of engine speed. The $\mathrm{CO}$ emissions are related with the combustion efficiency. The $\mathrm{CO}$ increases as the speed is reduced as a result of excessive enrichment of the fuel/air mixture, as indicated in Figure 4. Tung and its blend resulted in the highest emission of CO. Neat sunflower is equivalent to diesel 
oil. While the blend with sunflower increased the emission of $\mathrm{CO}$, the blend with soybean decreased the emission of $\mathrm{CO}$, becoming actually equivalent to the emission of diesel oil.

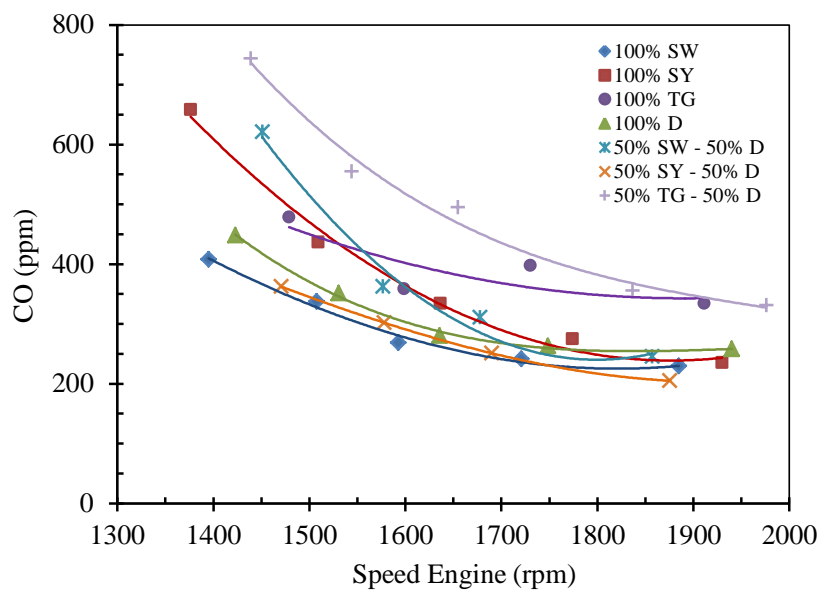

Figure 7. Mole fraction of $\mathrm{CO}$ in the exhausted gases versus engine speed.

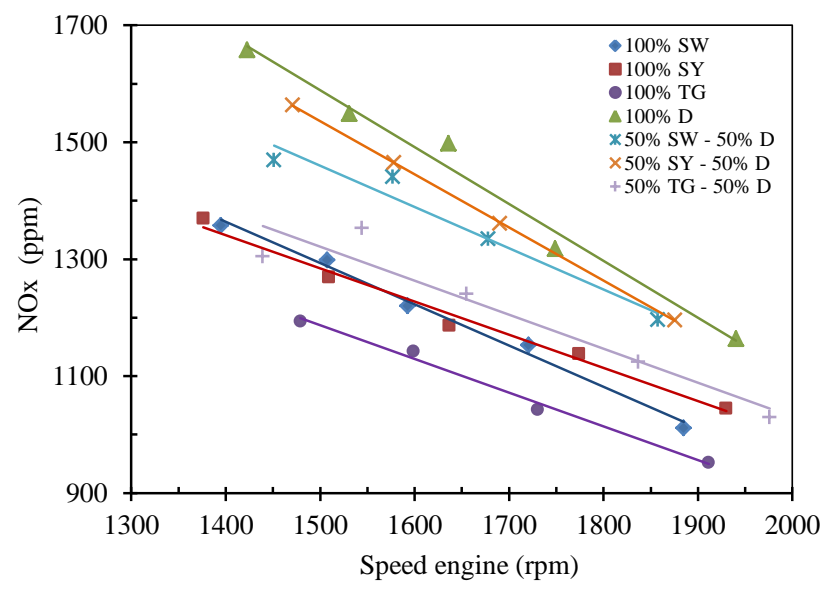

Figure 8. Mole fraction of $\mathrm{NO}_{x}$ in exhausted gases versus engine speed.

Figure 8 presents the mole fraction of $\mathrm{NO}_{\mathrm{x}}$ in the exhaust gases as a function of engine speed. $\mathrm{NO}_{\mathrm{x}}$ is formed in lean mixtures, when the combustion occurs under higher temperature, and for fuels containing nitrogen. Soybean is the only $\mathrm{N}$ containing fuel, as reported in Table 6. This apparently has little or no effect, since both sunflower and soybean present the same $\mathrm{NO}_{\mathrm{x}}$ emission. To better understand the combined $\mathrm{CO}$ and $\mathrm{NO}_{\mathrm{x}}$ emission, figure 9 presents the measurements of $\mathrm{CO}$ and $\mathrm{NO}_{\mathrm{x}}$ for all the fuels and engine loads. For normal combustion in diesel engines, it is expected an inverse trend, i.e., $\mathrm{CO}$ decreases as $\mathrm{NO}_{\mathrm{x}}$ increases.

Here, for all fuels, both decrease as engine speed increases, but $\mathrm{CO}$ tends to flatten at higher speeds. This indicates that the mixture becomes too rich at low speed, but there is enough time for a more complete combustion of the fuel charge. Then, temperatures are higher, leading to higher $\mathrm{NO}_{\mathrm{x}}$ formation, $\mathrm{CO}$ is higher due to the richer mixture, and the fuel conversion efficiency increases at lower speeds. At higher speed, however, combustion is not complete. Then, the engine charge reaches lower final temperatures before opening of the exhaust valve, causing a decrease of $\mathrm{NO}_{\mathrm{x}}$ production. The poorer combustion tends to flatten the $\mathrm{CO}$ emission. The emission of particulates was not measured.

Figure 10 presents the temperature of the exhaust gases as a function of engine speed. All vegetable oils present lower exhaust gas temperature than diesel oil. The diesel fraction enhanced the conversion of the blends.

The behaviour of the exhaust temperature is in agreement with the discussion above.

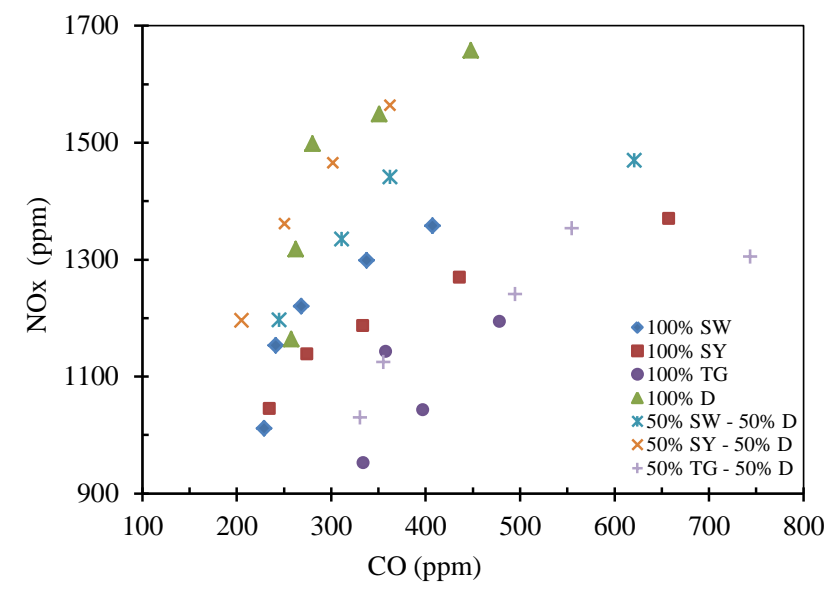

Figure 9. Exhaust gases mole fraction of $\mathrm{NO}_{x}$ versus $\mathrm{CO}$.

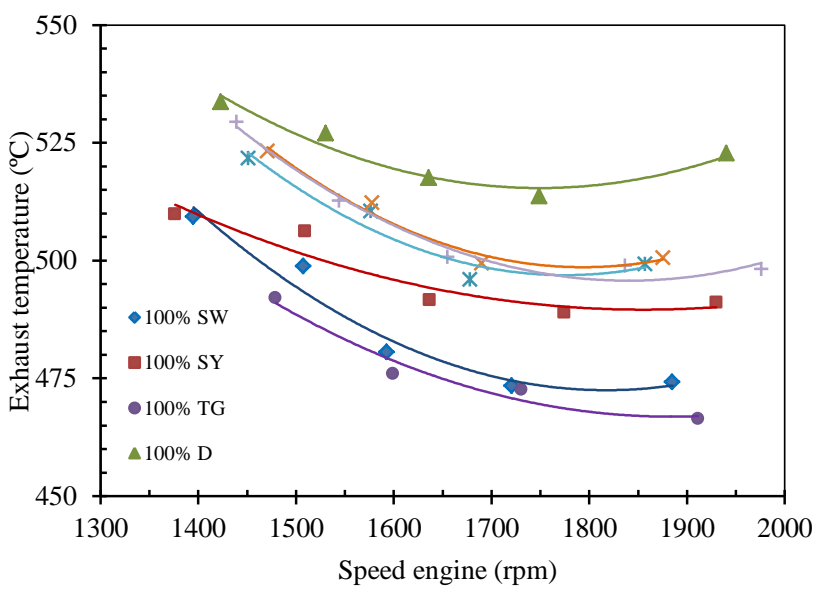

Figure 10. Temperature of the exhaust gases versus engine speed.

\section{Conclusions}

Here, we present the measurement of performance for a single-cylinder, naturally aspirated, mechanically controlled, CI engine operating with sunflower, soybean, and tung straight vegetable oils, as well as, their blends with diesel oil. In order to use the same injector and injection system, the SVO were heated to approximate their kinematic viscosity with that of diesel oil at ambient temperature. The heating system using exhaust heat and the controller were developed and installed in the engine. All oils presented the same mass of fuel injected per cycle at each engine speed, showing that the engine and heating strategy worked well for the straight vegetable oils and their blends. The output power and specific fuel consumption as a function of engine speed behaved in accordance with the values of LHV of the vegetable oils and their blends. The lower LHV of the SVO tested led to a decrease in power as well as to an increase in specific fuel consumption when compared to the operation with neat diesel oil. 
The results for thermal efficiency were particularly interesting. They showed that the thermal efficiency for sunflower and soybean oils are higher than that for the neat diesel oil. Besides, the best efficiencies (around 38 $\%$ ) were achieved by the $50 \%$ blend of sunflower, which are about $5 \%$ higher than that for neat diesel at $1600 \mathrm{rpm}$. Also, the blend of soybean presented thermal efficiencies higher than the diesel oil. Somehow, there is some improvement when the fuels are mixed. The reason for this behaviour is not clear at the moment. This is encouraging from the point of view of increasing the efficiency of electrical energy generation systems for isolated communities.

The $\mathrm{CO}$ emitted by the engine increased as the engine speed decreased. This occurred because the mechanical control of injection resulted in higher amount of fuel injected per cycle as the speed was reduced. The emission of $\mathrm{NO}_{\mathrm{x}}$ was also higher at lower speeds, as a result probably of better fuel conversion and longer residence time at lower speeds. The exhaust gas temperature was lower for the vegetable oils and their blends when compared to neat diesel, indicating that there is room to improve atomization and combustion. The use of a common rail injection system to provide injection pressures up to 800 bar may be a viable strategy to improve the fuel atomization and combustion, especially in the high speed regime.

\section{Acknowledgments}

The authors acknowledge the financial support of Eletrobrás - Eletrosul Centrais Elétricas S. A.

$\begin{array}{ll}\text { Nomenclature } & \\ \text { ANP } & \text { Agência Nacional de Petróleo } \\ \text { ASTM } & \text { American Society for Testing and } \\ \text { Materials } & \\ \text { BSFC } & \text { Brake Specific Fuel Consumption } \\ \text { CI } & \text { Compression Ignition } \\ \text { DI } & \text { Direct Injection } \\ \text { ECU } & \text { Electronic Control Unit } \\ \text { IDI } & \text { Indirect Injection } \\ \text { INT } & \text { National Institute of Technology } \\ \text { LHV } & \text { Lower Heating Value } \\ \text { SVO } & \text { Straight Vegetable Oil }\end{array}$

\section{References}

Agarwal, A. K. (2007). Biofuels (alcohols and biodiesel) applications as fuels for internal combustion engines. Progress in Energy and Combustion Science, 33(3), 233-271.

Agarwal, A. K., Rajamanoharan, K. (2009). Experimental investigations of performance and emissions of Karanja oil and its blends in a single cylinder agricultural diesel engine. Appl. Energy, 86(1), 106112.

Agarwal, D., Agarwal, A. K. (2007). Performance and emissions characteristics of Jatropha oil (preheated and blends) in a direct injection compression ignition engine. Appl. Therm. Eng., 27(13), 2314-223.

Aksoy, F. (2010). The effect of opium poppy oil diesel fuel mixture on engine performance and emissions. International Journal of Environment Science and Technology, 8(1), 57-62.
Almeida, S. C. A., Belchior C. R., Nascimento, M. V. G., Vieira L. Dos S. R. \& Fleury, G. (2002). Performance of a Diesel Generator Fuelled with Palm Oil. Fuel, 81(16), 2097-2102.

Altin, R. Cetinkaya, S. \& Yucesu, H. S. (2001). The potential of using vegetable oil fuels as fuel for diesel engines. Energy conversion and management, 42(5), 529-538.

Altun, S., Oner, C. (2009). Biodiesel production from inedible animal tallow and an experimental investigation of its use as alternative fuel in a direct diesel engine. Applied Energy, 86(10), 2114-2120.

Amba, P. R. G., Rama, M. P. (2003). Effect of Supercharging on performance of DI Diesel engine with cotton seed oil. Energy Conversion and Management, 44(6), 937-944.

Andrade, R. M. T., Miccolis, A. (2010). Biodiesel in the Amazon. World Agroforestry Centre, ICRAF Working Paper $N^{\circ} 113$. Nairobi, Kenya.

Antwi, E. (2008). Experimental analysis of vegetable oil blends in a compression ignition (CI) engine (Master Thesis), Kwame Nkrumah University of Science and Technology, Ghana.

Babu, A. K., Devaradjane, G. (2003). Vegetable oils and their derivatives as fuels for CI engines: An Overview. SAE Technical Paper 2003-01-0767.

Balafoutis, A., Fountas, S., Natsis, A. \& Papadakis, G. (2011). Performance and Emissions of Sunflower, Rapeseed, and Cottonseed Oils as Fuels in an Agricultural Tractor Engine. ISRN Renewable Energy, 2011.

Bari, S., Roy, M. M. (1995). Prospect of rice bran oil as an alternative to diesel. Proc. of the Fifth Int. Conf. on small engines, their fuels and the environment. The University of Reading, UK, 31-36.

Barsic, N. J., Humke, A. L. (1981). Performance and emissions characteristics of a naturally aspirated diesel engine with vegetable oil fuels. SAE Technical Paper 810262.

Belchior, C. R. P., Pimentel, V. S. B. (2005). The use of palm oil in diesel engine. 18th International Congress of Mechanical Engineering, Ouro Preto, MG, Brazil.

Bettis, B. L., Peterson, C. L., Auld, D. L. , Driscoll, D. J. \& Peterson, E. D. (1982). Fuel characteristics of vegetable oil from oilseed crops in the Pacific Northwest. Agronomy Journal, 74(2), 335-339.

Bhattacharya, S., Reddy, C. S. (1994). Vegetable oils as Fuel for Internal combustion Engines: A Review. Journal of Agricultural Engineering Research, 57(3), 157-166.

Bialkowski, M. T., Pekdemir, T., Reuben, R., Brautsch, M., Towers, D. P. \& Elsbett, G. (2005). Preliminary Approach Towards a CDI System Modification Operating on Neat Rapeseed Oil. Journal of KONES Internal Combustion Engines, 12(1), 1-12.

Chalatlon, V., Roy, M. M., Dutta, A. \& Kumar, S. (2011). Jatropha oil production and an experimental 
investigation of its use as an alternative fuel in a DI diesel engine. JPTAF, 2(5), 76-85.

Chang, C. C., Wan, S. W. (1947). China's Motor Fuels from Tung Oil. Ind. Eng. Chem, 39(12), 1543-1548.

Chauhan, B. S., Kumar, N., Jun, Y. D. \& Lee, K. B. (2010). Performance and emission study of preheated Jatropha oil on medium capacity diesel engine. Energy, 35(6), 2484-2492.

CONAB. (2011). Brazilian Crop Assessment: Grain, National Company of Food Supply. Third Assessment, Brasilia, Brazil.

Dwivedi, D., Agarwal, A. K. \& Sharma, M. (2006). Particulate Emission Characterization of a Biodiesel vs. Diesel-Fuelled Compression Ignition Transport Engine: A Comparative Study. Atmospheric Environment, 40(29), 5586-5595.

Engelman, H. W., Guenther, D. A. \& Silvis, T. W. (1978). Vegetable oil as a diesel fuel. Diesel and Gas Engine Power Division of ASME Paper, Number 78DGP-19, New York, NY: ASME.

Fontaras, G., Samaras, Z. \& Miltsios, G. (2007). Experimental evaluation of cottonseed oil- diesel blends as automotive fuels via vehicle and engine measurements. SAE Technical Paper 2007-24-0126.

Forson, F. K., Oduro, E. K. \& Hammond-Donkoh, E. (2004). Performance of Jatropha oil blends in a diesel engine. Renewable Energy. 29(7), 1135-1145.

Franco, Z., Nguyen, Q. D. (2011). Flow properties of vegetable oil-diesel fuel blends. Fuel, 90(2), 838-843.

Giannelos, P. N., Zannikos, F., Stournas, S. \& Anastopoulos, G. (2002). Tobacco seed oil as an alternative diesel fuel: physical and chemical properties. Industrial Crops and Products, 16(1), 1-9.

Hazar, H., Aydin, H. (2010). Performance and emission evaluation of a CI engine fuelled with preheated raw rapeseed oil (RRO)-diesel blends. Appl. Energy, 87(3), 786-790.

He, Y., Bao, Y. D. (2005). Study on cottonseed oil as a partial substitute for diesel oil in fuel for singlecylinder diesel engine. Renewable Energy, 30(5), 805813.

Heywood, J. B. (1988). Internal Combustion Engine Fundamentals. New York, NY: McGraw-Hill Inc.

Isigigur, A., Karaosmanoglu, F., Aksoy, H. A., Hamdullahpur, F. \& Gulder, O. L. (1993). Safflower seed oil of Turkish origin as a diesel fuel alternative. Applied Biochemistry and Biotechnology, 40, 89-105.

Kalam, M. A., Husnawan, M. \& Masjuki, M. H., (2003). Exhaust emission and combustion evaluation of coconut oil-powered indirect injection diesel engine. Renewable Energy, 28(15), 2405-2415.

Karaosmanoglu, F., Kurt, G. \& Özaktaş, T. (2000). Long term CI engine test of sunflower oil. Renewable Energy, 19(1-2), 219-221.

Kleinova, A., Vailing, I., Franta, R., Mikulec, J. \& Cvengroš, J. (2009). Vegetable oils as diesel fuels for rebuilt vehicles. 44th International Petroleum Conference, Bratislava, Slovak Republic.

Knothe, G. (2001). Historical Perspectives on Vegetable Oil-Based Diesel Fuels. Inform, 12, 103-1107.

Knothe, G., van Gerpen, J. \& Krahl, J. (2005). The Biodiesel Handbook. Champaign, IL: AOCS Press.

Kumar, M. S., Ramesh, A. \& Nagalingam, B. (2003). An experimental comparison of methods to use methanol and Jatropha oil in a compression ignition engine. Biomass \& Bioenergy, 25(3), 309-318.

Luo, L., van der Voet, E. \& Huppes, G. (2009). Life cycle assessment and life cycle costing of bioethanol from sugarcane in Brazil. Renewable and Sustainable Energy Reviews, 13(6-7), 1613-1619.

Macedo, I. C., Leal, M. R. L. V. \& Silva, J. E. A. R. (2004). Assessment of Greenhouse Gas Emissions in the Production and Use of Fuel Ethanol in Brazil. State Secretariat of the Environment, São Paulo, Brazil.

Martin, M., Prithviraj, D. (2011). Performance of Preheated Cottonseed Oil and Diesel Fuel Blends in a Compression Ignition Engine. Jordan Journal of Mechanical and Industrial Engineering, 5(3), 235240.

Martines-Filho, J., Burnquist, H. \& Vian, C. (2006). Bioenergy and the Rise of Sugarcane-Based Ethanol in Brazil. CHOICES 2nd Quarter, 21(2), 91-96.

Maziero, J. V. G., Corrêa, M., Úngaro, M. R., Bernardi, J. A. \& Storino, M (2007). Diesel Engine Performance With Raw Sunflower Oil Fuel, R. Bras. Agrociência, 13(2), 249-255.

Mondal, P., Basu, M. \& Balasubramanian, N. (2008). Direct use of vegetable oil and animal fat as alternative fuel in internal combustion engine. Biofuels, Bioproducts and Biorefining, 2(2), 155-174.

Naga, P. C. S., Vijaya, K. R. K., Kumar, B. S. P., Ramjee, E., Hebbel, O.D. \& Nivendgi, M. C. (2009). Performance and emission characteristics of a diesel engine with castor oil, Indian J.Sci.Technol., 2(10), 25-31.

No, S. Y. (2011). Inedible vegetable oils and their derivatives for alternative diesel fuels in CI engines: A review. Renewable Sustain. Energy Rev., 15(1), 13114.

Nwafor, O. M. I. (2003). The effect of elevated fuel inlet temperature on performance of diesel engine running on neat vegetable oil at constant sspeed conditions. Renewable Energy, 28(2), 171-181.

Nwafor, O. M. I., Rice, G. (1996). Performance of rapeseed oil blends in a diesel engine. International Journal of Applied Energy, 54(4), 345-354.

Ometto, A. R., Hauschild, M. Z. \& Roma, W. N. L. (2009). Lifecycle assessment of fuel ethanol from sugarcane in Brazil. The International Journal of Life Cycle Assessment, 14(3), 236-247.

Peterson, C. L., Auld, D. L. \& Korus, R. A. (1983). Winter rape oil fuel for diesel engines: Recovery and 
utilization. Journal of the American Oil Chemists' Society, 60(8), 1579-1587.

Pimentel, V. S. De B., Belchior, C. R. \& Pereira, P. P. (2004). Avaliação Experimental do Desempenho e Emissões de Motores Diesel Usando Misturas de Óleo de Mamona e Óleo Diesel. AGRENER 2004: Proceedings of the 16Th Conference on Rural Energy, Brasilia-DF, Brazil, 504-513.

Pousa, P. A. G., Santos, A. L. F. \& Suarez, P. A. Z. (2007). History and policy of biodiesel in Brazil. Energy Policy, 35(11), 5393-5398.

Pramanik, K. (2003). Properties and use of Jatropha oil and diesel blends in compression ignition engine. Renewable Energy, 28(2), 239-248.

Pryor, R. W., Hanna, M. A., Schinstock, J. L. \& Bashford, L. L. (1983). Soybean oil fuel in a small diesel engine. Transactions of the ASAE, 26(2), 333-337.

Pugazhvadivu, M., Sankaranarayanan, G. (2010). Experimental studies on a diesel engine using mahua oil as fuel. Indian J.Sci.Technol., 3(7), 787-791.

Raghu, R., Ramadoss, G., Sairam, K. \& Arulkumar, A. (2011). Experimental Investigation on the Performance and Emission Characteristics of a DI Diesel Engine Fueled with Preheated Rice Bran Oil European. Journal of Scientific Research, 64(3), 400414.

Rakopoulos, D. C., Rakopoulos, C. D., Giakoumis, E. G., Dimaratos, A. M. \& Founti, M. A. (2011). Comparative environmental behaviour of bus engine operating on blends of diesel fuel with four straight vegetable oils of Greek origin: Sunflower, cottonseed, corn and olive. Fuel, 90(11), 3439-3446.

Sapaun, S. M., Masjuki, H. H. \& Azlan, A. (1996). The use of palm oil as diesel substitute. Journal of Power and Energy, 210(1), 47-53.

Sarada, S. N., Shailaja, M., K. \& Kalyani, R. (2010). Optimization of injection pressure for a compression ignition engine with cotton seed oil as an alternate fuel. International Journal of Engineering, Science and Technology, 2(6), 142-149.

Shahid, E. M., Jamal, Y. (2011). Production of Biodiesel: A Technical Review. Renewable and Sustainable Energy Reviews, 15(9), 4732-4745.

Sidibé, S. S., Blin, J., Vaitilingom, G. \& Azoumah, Y. (2010). Use of crude filtered vegetable oil as a fuel in diesel engines state of the art: Literature review. Renewable and Sustainable Energy Reviews, 14(9), 2748-2759.

Sinha, S., Misra, N. C. (1997). Diesel fuel alternative from vegetable oils. Chem. Eng. World, 32(10), 77-80.

Sivalakshmi, S., Balusamy, T. (2011). Experimental investigation on a diesel engine using neem oil and its methyl ester. Thermal Science Year, 15(4), 11931204.

Thaddeus, H. C. M., Asuyuki, S. \& Okobatae, T. (2001). Operation and Combustion Characteristics ofa a DI Diesel Engine Fueled with Biomass Oil-Diesel. SAE Technical Paper 2001-28-0030.

Venkanna, B. K., Swati, B. \& Reddy, C. V. (2009). Effect of Injection Pressure on Performance, Emission and Combustion Characteristics of Direct Injection Diesel Engine Running on Blends of Pongamia Pinnata Linn Oil (Honge oil) and Diesel Fuel. Agricultural Engineering International: CIGR Journal, 11, 13161323.

Yaodong, W., Huang, Y., Roskilly, A. P., Ding, Y. \& Hewitt, N. (2010). Trigeneration running with raw jatropha oil. Fuel Processing Technology, 91(3), 348353.

Yilmaz, N., Morton, B. (2011). Effects of preheating vegetable oils on performance and emission characteristics of two diesel engines. Biomass \& Bioenergy., 35(5), 2028-2033. 